УДК 336.647/648

\title{
АКТУАЛЬНЫЕ ПРОБЛЕМЫ НЕСОСТОЯТЕЛЬНОСТИ ЮРИДИЧЕСКИХ ЛИЦ С УЧАСТИЕМ ТРАНСНАЦИОНАЛЬНОГО КАПИТАЛА
}

\section{Нечкин Олег Сергеевич}

соискатель ученой степени кандидата экономических наук

\begin{abstract}
Аннотация: в статье освещаются актуальные проблемы признания несостоятельными (банкротами) транснациональных корпораций и компаний с участием зарубежного капитала, об отсутствии законодательного положения, предусматривающего признание иностранных банкротств на территории РФ. Рассматриваются особенности проведения финансового анализа деятельности юридического лица в деле о несостоятельности (банкротстве) и различия российских положений по бухгалтерскому учету (ПБУ) и международных стандартов финансовой отчетности (МСФО).

Ключевые слова: транснациональные компании, трансконтинентальные корпорации, зарубежные активы, мировые стандарты, трансграничное банкротство, несостоятельность, финансовый анализ, оценка несостоятельности.
\end{abstract}

\section{CURRENT PROBLEMS INSOLVENCY THE LEGAL ENTITIES INVOLVING TRANSNATIONAL CAPITAL}

Nechkin Oleg S.

\begin{abstract}
The article highlights the current problems of recognition of insolvent (bankrupt), transnational corporations and companies with foreign capital, the lack of legal provision for the recognition of foreign bankruptcies in the territory of the Russian Federation. The features of the financial analysis Dey-telnosti legal person in the insolvency (bankruptcy) and differences Russian accounting regulations (FDR) and the International Financial Reporting Standards (IFRS).

Key words: multinational companies, multinational corporations, foreign assets, global standards, cross-border bankruptcy, insolvency, financial analysis, evaluation of insolvency.
\end{abstract}


Предметом изучения в статье являются компании с участием транснационального капитала, предприятия, владеющие производственными подразделениями в нескольких странах и корпорации, на зарубежные активы которой приходится порядка 25-30 \% общего объёма и имеющая филиалы в двух и более принимающих странах (прим. принимающие страны - страны, в которых размещена собственность компании).

Компании с участием транснационального капитала обеспечивают около 50\% мирового промышленного производства, включая более 70\% мировой торговли, при этом 40 \% этой торговли происходит внутри корпорации и происходят не по рыночным ценам, а по трансфертным ценам, которые формируются под долгосрочной политикой материнской корпорации, монополизирующая производство как в масштабе отдельных стран, так и в масштабе мирового хозяйства в целом оказывая существенное влияние на экономические индексы. Ha долю транснациональных компаний приходится более 80\% зарегистрированных патентов и финансирования научных, конструкторских и исследовательских разработок.

Транснациональные компании могут включать в состав консолидированной группы кредитные организации, телекоммуникационные, страховые и аудиторские компании, инвестиционные и пенсионные фонды. Несостоятельность трансграничного масштаба и групп компаний (в пример можно привести дело Lehman Brothers, в котором было возбуждено 75 производств по делам о несостоятельности в 16 государствах, банкротстве компании Maxwell Communication Corporation, где процедуры несостоятельности велись в Великобритании и США) стимулируют создавать новые механизмы и эффективные меры проведения процедуры несостоятельности, выходящей за пределы одного государства.

Введение в российском праве понятия трансграничного банкротства подразумевает, что имеет место иностранный кредитор и/или иностранный должник, либо имущество должника, на которое обращается взыскание, находится в нескольких государствах, либо права требования к должнику возникли в ином государстве. Сложность банкротства транснациональных компаний заключается в том, что у каждого государства существуют внутренние национальные нормы, регулирующие вопросы несостоятельности. Правовые системы государств по-разному относятся к защите интересов кредиторов, определению прав управляющих, и к задачам правового регулирования отношений, возникающих в деле о несостоятельности. Англия, по сравнению с иными странами, защищает кредиторов, американская модель менее либе- 
ральна к кредиторам и сочетает защиту интересов должника с санацией предприятий и корпораций, тогда как цель Франции - оздоровление предприятий в ущерб кредиторам. (Среди основных рекомендательных актов можно выделить следующие: руководство для законодательных органов по вопросам законодательства о несостоятельности; Практическое руководство ЮНСИТРАЛ; Унифицированный акт ОХАДА «Об организации коллективных процедур ликвидации»; Принципы сотрудничества по делам о банкротстве между странами НАФТА.) Вместе с тем, на сегодняшний день международных договоров с участием России по вопросам банкротств нет.

В марте 2011 года, Министерство Экономического развития представило проект Федерального Закона «О трансграничной несостоятельности (банкротстве)». За основу законопроекта взят разработанный комиссией Организации Объединенных Наций международной торговли типовой закон «ЮНСИТРАЛ» по вопросам сотрудничества в делах о трансграничной несостоятельности и практика применения Регламента Совета Европейского Союза о производстве по делам о несостоятельности. [1] [5]

Стоит отметить, что проблемой при признании банкротом транснациональной компании, становится вопрос о международной подсудности дела о банкротстве, применимом праве и механизмах признания иностранных банкротств (в том числе признания и приведения в исполнение судебных актов по делу о несостоятельности за рубежом и признании иностранных судебных актов по делам о банкротстве на территории РФ), практике подхода к анализу финансового состояния должника сформированной в соответствии с Международными Стандартами Финансовой Отчетности (далее по тексту МСФО) и как следствие об оценке причин несостоятельности.

Речь идет об отсутствии законодательного положения, которое позволило бы возбудить производство по делу о несостоятельности в отношении иностранных лиц. Возбуждение производства по делу о несостоятельности в российском суде возможно только в отношении российских юридических лиц, местом нахождения которого является место его государственной регистрации, (прим. - критерий инкорпорации) которое должно совпадать с местом нахождения постоянно действующего исполнительного органа. В то же время Россия признает иностранные юридические лица, созданные за рубежом.

Отсутствие современного инструмента для возбуждения производства по делу о несостоятельности в отношении компаний, имеющие регистрацию за пределами Российской Федерации, оставляет Россию вне сферы регулирования банкротств транснациональных компаний. Учитывая, что на сегодняшний день 
не создано эффективных механизмов признания иностранных банкротств в глобальном масштабе, Российская Федерация может стать объектом недосягаемости для иностранных судов и кредиторов, что может быть использовано с целью сокрытия активов должника.

Увеличение числа роста трансконтинентальных корпораций и компаний с участием транснационального капитала, должно способствовать созданию механизма признания их несостоятельными. В особенности это важно, когда транснациональная компания является дочерней, зависимой, совместным предприятием или иным подконтрольным лицом, а центр принятия решений и деловой активности находится на территории иного государства. В данном случае использование в государстве критерия инкорпорации для инициирования банкротного производства порождает обход законодательства со стороны бизнеса любой государственной принадлежности, имеющий корпоративную форму иностранного юридического лица и продолжающего свою деятельность в РФ вне досягаемости законодательства о банкротстве.

Таким образом, при введении норм закона, с одной стороны, важно учесть интерес в локализации на территории Российской Федерации производств о транснациональной несостоятельности, с другой - обеспечить изначальную предсказуемость регулирования трансграничных банкротств для субъектов экономической деятельности, с обеспечением интереса в виде сохранения и повышения инвестиционной привлекательности государства. [6]

В целях определения достаточности имущества должника для покрытия расходов в деле о банкротстве, а также для определения возможности или невозможности восстановления платежеспособности должника арбитражный управляющий проводит анализ финансового состояния. Заключение по финансовому анализу готовится в соответствии со ст. 67, 70 Федерального Закона. «О несостоятельности (банкротстве)», с соблюдением Правил по проведению арбитражными управляющими финансового анализа, утвержденных постановлением Правительства РФ от 25.06.2003 г. № 367.

При проведении финансового анализа управляющий анализирует финансовое состояние должника на дату проведения анализа, его финансовую, хозяйственную и инвестиционную деятельность, положение на товарных и иных рынках. Согласно утвержденным рекомендациям для расчета финансовохозяйственной деятельности должника используются основные показатели деятельности должника: коэффициенты платёжеспособности должника, коэффициенты финансовой устойчивости, коэффициенты деловой активности и прочее. [3] [4] 
Вместе с тем, различия российских положений по бухгалтерскому учету (ПБУ) и МСФО проявляются уже на уровне финансовой (стоимостной) оценки, в процедурах признания и раскрытия в отчетности отдельных видов активов, обязательств, капитала, доходов, расходов, потоков денежных средств и финансовых результатов. В частности, раскрытие информации в финансовой отчётности по МСФО более субъективно, поскольку в большей степени зависит от субъективного профессионального суждения менеджмента.

Необходимо учесть, что мировые стандарты предусматривают более широкий объем специальных инструментов, которые не используются обычными юридическими лицами: неконвертируемые обязательства (облигации), деривативы (опционы и фьючерсные контракты на внешнюю, международную, мировую торговлю товарами, услугами, технологиями и объектами интеллектуальной собственности), влияние изменений валютных курсов, консолидации и слияния групп, опционы под выдачу заработной платы, платежи с использованием акций, финансовые вложения в виде приобретаемых ценных бумаг, влияние СМИ и финансовых рынков в ходе раскрытия информации.

Существенные различия в раскрытии показателей финансовой отчетности по российским правилам и финансовой отчетности в соответствии с МСФО, отражаются на результатах финансового анализа и оценки несостоятельности хозяйствующих субъектов с участием транснационального капитала. [8]

Проведение финансового анализа деятельности транснациональной компании, оценка причин утраты его платежеспособности, выявление признаков фиктивного и преднамеренного банкротства а также достоверное определение и выявление активов должника с учетом стран базирования и места его фактического нахождения с целью формирования конкурсной массы, требует абсолютно иного подхода к проведению анализа финансовой отчетности сформированной в соответствии с МСФО и деятельности транснациональной компании в целом.

В совокупности, указанные обстоятельства, в первую очередь прямо влияют на интересы отечественных кредиторов в деле о несостоятельности (банкротстве), а также иностранных кредиторов с инициативой возбуждения производства на территории тех государств, где находятся активы несостоятельного должника и затрудняют совершенствование механизма оценки несостоятельности компаний и корпораций с участием транснационального капитала. 


\section{Список литературы}

1. Типовой закон Комиссии ООН по праву международной торговли о трансграничной несостоятельности 1997 г. Принят в Вене 30.05.1997 на 30-й сессии ЮНСИТРАЛ.

2. Федеральный закон "О несостоятельности (банкротстве)" от 26 октября 2002 г. № 127 - Ф3;

3. Временные правила проверки арбитражным управляющим наличия признаков фиктивного и преднамеренного банкротства: утв. Постановлением Правительства РФ от 27 декабря 2004 г. № 855.

4. Правила проведения арбитражным управляющим финансового анализа: утв. Постановлением Правительства РФ от 25 июня 2003 г. № 367.

5. Проект Федерального закона «О трансграничной несостоятельности (банкротстве). Министерство Экономического развития Российской Федерации (Минэкономразвития России).

6. Мохова Е.В., Статья «Центр основных интересов должника при трансграничной несостоятельности».

7. Собина Л.Ю., Статья «Признание иностранных банкротств в международном частном праве».

\section{References}

1. UNCITRAL Working Group V (Insolvency) 28th session, New York, 2428.02.2003. A/CN.9/WG.V/WP.63/Add.1. 29th session. Vienna, 01-05.09.2003. A/CN.9/WG.V/WP.67. Vienna, A/CN.9/442 19.12.1997 (www.uncitral.org).

2. Federal Law "On Insolvency (Bankruptcy)" 26.09.2002 № 127.

3. The temporary inspection rules liquidator Naliences signs of fictitious and deliberate bankruptcy: approved. Post-of the Government of the Russian Federation of December 27, 2004 № 855.

4. The rules of the arbitration manager of financial analysis: approved. Russian Federation Government Decree of June 25, 2003 № 367.

5. Draft Federal Law "On Cross-Border Insolvency (bankruptcy). Ministry of Economic Development of the Russian Federation.

6. E.V. Mokhova, "Center of main interests of the debtor in cross-border insolvency".

7. L.Y. Sobina, "Recognition of foreign bankruptcies in-between private international law".

(C) О.С. Нечкин, 2021 